Published Online on 9 July 2018

Proc Indian Natn Sci Acad $\mathbf{8 4}$ No. 3 September 2018 pp. 723-729

(C) Printed in India.

DOI: $10.16943 /$ ptinsa/2018/49400

Research Paper

\title{
Toxicity Analysis and cry Gene Profiling of Bacillus thuringiensis Isolated from Western Ghats of Tamil Nadu State, India
}

\author{
A RAMALAKSHMI, P ANNAKODI, V UDAYASURIAN* and V BALASUBRAMANI \\ Centre for Plant Molecular Biology, Tamil Nadu Agricultural University, Coimbatore 641 003, Tamil \\ Nadu, India
}

(Received on 11 December 2017; Revised on 16 April 2018; Accepted on 08 May 2018)

\begin{abstract}
Insect bioassays and PCR screening with specific primers are the two techniques widely followed for identification of novel cry genes from new isolates of Bacillus thuringiensis $(\mathrm{Bt})$. In the present study, seventy new isolates of Bt isolated from the Western Ghats were evaluated for its toxicity against Helicoverpa armigera (Hubner) and for the presence of cry genes through PCR screening with specific primers. The isolates showing 90 to 100,50 to 89 and less than 50 per cent mortality of $H$. armigera were categorised into group I, II and III respectively. Eight and fourteen new isolates of Bt were grouped under I and II, respectively. Whereas 48 new isolates of Bt were clustered under the group III. The group I isolates were positive for cry 1, cry 2 and cry 9 and negative for cry 3 and cry 4 genes. Five different cry genes viz., cry 1, cry 2, cry3, cry 4 and $\operatorname{cry} 9$ were found in group II isolates. All 48 isolates under group III were not positive for cry 3 gene. Similarly, 20 of 48 isolates of group III were negative for all the five $c r y$ genes tested. The remaining 28 isolates were positive for one or more of the following cry genes: viz., cry1, cry2, cry 4 and cry9. Of the 70 new isolates screened for cry genes, cry 1, cry2, cry 4 and cry 9 genes were observed in 41.4 and 35.7, 12.8 and 15.7 per cent of the isolates, respectively.
\end{abstract}

Key words: B. thuringiensis; Western Ghats; H. armigera; cry Gene Profiles

\section{Introduction}

Indiscriminate use of chemical pesticides has longterm detrimental effects on soil crop and environment in total. It is estimated that globally around 500 pesticides are in use, India alone uses 250 different pesticides. However, studies reveal that only $1 \%$ of the pesticide reaches the target and remaining 99\% are released in to the environment. This leads to environmental degradation, elimination of natural parasitoids and predators; and the residues are entering into human food chain. Besides that, continuous exposure of several pesticides to insect pests results in development of resistance to one or more chemical insecticides. Biological control of pests using $B$. thuringiensis $(\mathrm{Bt})$ products has advantages over chemical pesticides due to its specific toxicity against target insects, lack of polluting residues and safety to non-target organisms such as mammals, birds, amphibians and reptiles. Bt is a Gram positive, sporulating soil bacterium that forms insecticidal crystal proteins during sporulation phase of its growth. $\mathrm{Bt}$ is the major source for development of insectresistant transgenic plants. Several isolates have been tested and characterized against insect pests and disease for production of biopesticides. The development of such bio pesticides leads to reduction in chemical pesticide use. The use of biotech crops has reduced pesticide spraying by 352 million $\mathrm{kg}$ ($8.4 \%$ ) and, as a result, decreased the environmental impact associated with herbicide and insecticide use on these crops (as measured by the indicator the environmental impact quotient) by $16.3 \%$ (Brookes and Barfoot, 2010). In this regard, intensive screening programmes are carried out worldwide to isolate large number of $\mathrm{Bt}$, in order to identify new strains of $\mathrm{Bt}$ with increased levels of insecticidal activity against a broader spectrum of insect pests for development of Biotech crops. It is also reported that new variants of the already known cry gene subgroups could encode crystal proteins with significant difference in the level

*Authorfor Correspondence: E-mail: udayvar@yahoo.com 
and spectrum of toxicity due to variation in their sequences (Xue et al., 2008). In our previous study, variation in morphology of crystalline inclusions and crystal protein profile were observed for 70 of $316 \mathrm{Bt}$ isolates from Western Ghats (Ramalakshmi and Udyasuriyan, 2010). Further screening of the new isolates for its toxicity against lepidopteran and for the presence of cry gene may result in novel cry genes. Hence, the present study was aimed to screen the 70 new isolates of $\mathrm{Bt}$ for its toxicity against neonatal larvae of $H$. armigera by artificial diet- basedbioassay and for the presence of cry genes by PCR screening.

\section{Materials and Methods}

\section{Sources of Bt Strains}

Seventy new isolates of $\mathrm{Bt}$ isolated from the Western Ghats and identified based on the crystal morphology were used for the present study (Ramalakshmi, and Udayasuriyan, 2010). The reference strains of Bt available with corresponding author were used for the present study.

\section{Toxicity Analysis of Bt Against Helicoverpa armigera}

A bioassay was performed to analyse the toxicity of Bt against lab grown culture of $H$. armigera (originally initiated from field-collected larvae), $H$. armigera was reared on a semi synthetic diet (Patel et al., 1968). The Bt isolates were grown in T3 broth till more than 90 per cent cell lysis occurred and then OD was measured at $600 \mathrm{~nm}$. The Bt cultures were subsequently equalized to $0.5 \mathrm{OD}$ and used for bioassay. Approximately one $\mathrm{ml}$ of the semi-synthetic diet was dispensed into $1.8 \mathrm{ml}$ cryovial (Tarson ${ }^{\circledR} ; 1 \mathrm{~cm}$ dia.) and allowed to dry for an hour. After solidification of the diet, the Bt culture broth was coated on the diet surface@10 $@$ l per vial using a sterile glass rod. The vials were allowed to dry for $30 \mathrm{~min}$ and to each vial a neonate larva of $H$. armigera was released using a soft hairbrush. They were closed halfway with a screw cap, leaving space for gas exchange. All the above steps were carried out under sterile conditions and controlled atmosphere. A treatment without $\mathrm{Bt}$ culture served as control and ten vials were maintained for each treatment with three replications. Larval mortality was recorded periodically for seven days. A larva was marked dead when they did not move even when prodded with hairbrush. All the experiments were carried out in a room with a photoperiod of 14:10 (L:D); and optimum temperature of $27^{\circ} \mathrm{C}$ and 60 per cent $\mathrm{RH}$.

\section{Genomic DNA Isolation}

Total genomic DNA was extracted from all 70 new isolates and four reference strains of Bt, as described by Kalman et al. (1993). Genomic DNA of Bt was quantified by loading on 0.8 per cent agarose gel with reference to known quantity of $\lambda /$ Hind III. The DNA samples were analysed by agarose gel electrophoresis as described by Sambrook et al. (1989).

\section{PCR Screening for cry Gene Content}

The new isolates of Bt were screened through PCR for the presence of cryl, cry2, cry3, cry 4 and cry 9 family gene(s). Details regarding primer sequences and amplicons size are given in Table 1. Total genomic DNA isolated from Bt strains was used as template for PCR screening with cry gene family primers. The PCR was accomplished using an Eppendorf thermal cycler in $25 \mu 1$ reaction volume containing $30 \mathrm{ng}$ of total genomic DNA of Bt, $2.5 \mu 1$ of $10 \mathrm{X}$ PCR buffer (10 mMTris- $\mathrm{HCl}$; pH: 9.0, $50 \mathrm{mM} \mathrm{KCl}, 1.5 \mathrm{mM}$ $\mathrm{MgCl}_{2}$ ), $75 \mu \mathrm{M}$ each of dNTPs, $50 \mathrm{ng}$ each of forward and reverse primers and 1.5 Units of Taq DNA polymerase. The PCR was performed for 30 cycles. Temperature profile for PCR screening of cry 1, cry 2 , cry 3, cry 4 and $c r y 9$ genes were as per reference cited in Table 1. An aliquot of amplified PCR product was analyzed on 1.2 per cent agarose gel.

\section{Results}

Results from the previous study (Ramalakshmi and Udayasuriyan, 2010) show that out of 70 new isolates of $\mathrm{Bt}$, six different types of crystal protein profile viz., 135 and $65,135,95,65,43$ and $30 \mathrm{kDa}$ were observed in $17(24.2 \%), 15(21.4 \%), 12(17.1 \%), 7$ (10\%), 4 $(5.7 \%)$, and $7(10 \%)$ Bt isolates, respectively and the remaining eight $\mathrm{Bt}$ isolates did not show any distinct band of crystal protein. The results of the present study on toxicity analysis of 70 new isolates of $\mathrm{Bt}$ are presented in Fig. 1. The isolates Nn1, Ns1and Nn10 recorded 100 per cent mortality of $H$. armigera, similar to reference strain $\mathrm{Bt}, \mathrm{HD} 1$. The 17 new isolates of Bt having crystal proteins of 135 and 65 kDa recorded 16.7 to 100 per cent mortality in $H$. 
Table 1: Primers used for screening of cry genes

\begin{tabular}{|c|c|c|c|c|}
\hline S.No. & Primer sequences & crygenes & $\begin{array}{l}\text { Amplicon } \\
\text { size (bp) }\end{array}$ & References \\
\hline 1. & $\begin{array}{l}\text { FP: 5'CATGATTCATGCGGCAGATAAAC 3' } \\
\text { RP: 5'TTGTGACACTTCTGCTTCCCATT 3' }\end{array}$ & cryl & 277 & Ben-dov et al. (1997) \\
\hline 2. & $\begin{array}{l}\text { FP: 5'GTTATTCTTAATGCAGATGAATGGG 3', } \\
\text { RP: 5'CGGATAAAATAATCTGGGAAATAGT 3', }\end{array}$ & $\operatorname{cry} 2 A$ & 700 & Ben-dov et al. (1997) \\
\hline 3. & $\begin{array}{l}\text { FP: 5'CGTTATCGCAGAGAGATGACATTAAC 3' } \\
\text { RP: 5'CATCTGTTGTTTCTGGAGGCAAT 3' }\end{array}$ & cry3 & 590 & Ben-dov et al. (1997) \\
\hline 4. & $\begin{array}{l}\text { FP: 5'GCATATGATGTAGCGAAACAAGCC 3', } \\
\text { RP: 5'GCGTGACATACCCATTTCCAGGTCC 3' }\end{array}$ & cry 4 & 440 & Ben-dov et al. (1997) \\
\hline 5. & $\begin{array}{l}\text { FP: 5'CGGTGTTACTATTAGCGAGGGCGG 3' } \\
\text { RP: 5'GTTTGAGCCGCTTCACAGCAATCC 3' }\end{array}$ & crys & 350 & Ben-dov et al. (1999) \\
\hline
\end{tabular}

FP: forward primer; RP: reverse primer

armigera. The Bt isolates, Po29 and Co3 showed 93.3 and 90 per cent mortality, respectively. The remaining 12 isolates showed different levels of toxicity (10 to 80 per cent) at 7 DAT. All the isolates of 95 $\mathrm{kDa}$ showed less than 50 per cent mortality except the isolate, Ko19 which showed fifty per cent mortality at 7 DAT. All the seven isolates of $65 \mathrm{kDa}$ crystal proteins showed mortality to $H$. armigera in the range of 30 to 100 per cent. The isolates, Gu2 and Mu12 recorded 96.7 and 90.0 per cent mortality respectively, whereas the Bt isolate, Co37 recorded lowest mortality (30 per cent) at 7 DAT. The Four new isolates of Bt having $\sim 43 \mathrm{kDa}$ crystal protein(s) showed less than fifty per cent mortality at 7 DAT. The Bt isolate, Di11 having crystal protein of $\sim 30 \mathrm{kDa}$ showed 76.7 per cent mortality, whereas the remaining six isolates showed less than 50 per cent mortality at 7 DAT. The eight new isolates of $\mathrm{Bt}$ showing no discrete bands of crystal protein showed less than 50 per cent mortality at 7 DAT. Based on level of toxicity against $H$. armigera, the 70 new isolates of Bt were classified into three groups. The isolates showing 90 to 100 were grouped as I, 50 to 89 are II and less than 50 per cent were grouped as III respectively. Eight and fourteen new isolates of Bt were of group I and II, respectively, whereas 48 new isolates of Bt were clustered under the group III (Table 2). All the 70 new isolates of Bt were screened by PCR for the presence of five different cry genes viz., cryl, cry2, cry3, cry4 and cry9 using gene specific primers (Fig. 2). The reference strain of $\mathrm{Bt}, \mathrm{HD} 1$ was used as a positive control for cryl and cry 2 genes and the reference strains, Btt, Bti and 14R1 were used as a positive
Table 2: Grouping of $B$. thuringiensis isolates of Western Ghats based on toxicity level against $H$. armigera

\begin{tabular}{lcccc}
\hline \multirow{2}{*}{$\begin{array}{c}\text { S.No. Grouping of Bt isolates based on } \\
\text { toxicity against } \\
\text { Group }\end{array}$} & \multicolumn{2}{c}{ Bt ismigera } \\
\cline { 3 - 5 } & $\begin{array}{c}\text { Mortality on } \\
\text { number }\end{array}$ & Number & Per cent \\
\hline 1 & I & $90-100$ & 8 & 11.4 \\
2 & II & $89-50$ & 14 & 20.0 \\
3 & III & $0-50$ & 48 & 68.6 \\
& Total & $\mathbf{7 0}$ & & \\
\hline
\end{tabular}

control for cry3, cry 4 and cry9, respectively. All the eight isolates under group I gave amplification for one or more of the following cry genes viz., cryl, cry 2 and cry9 (Table 3) whereas none of the Bt isolates of group I gave amplification for cry 3 and cry 4 genes. Among the fourteen isolates of group II tested, four failed to give amplification for all the five cry genes tested. The remaining ten isolates had one or more of the following the cry genes viz., cry1, cry 2 and cry9. All the fourteen isolates were not positive for cry3 and cry 4 genes. Twenty out of 48 isolates of group III failed to give amplification for all the five cry genes tested. The remaining 28 isolates had one or more of the following cry genes viz., cryl, cry2, cry 4 and cry9. All the 48 isolates did not show presence of cry3 gene (Table 4). Of the 70 isolates of $\mathrm{Bt}, 24$ isolates (34.3 per cent) failed to give amplification for all the five cry genes tested. The remaining 46 isolates gave amplification for one or more of the following four cry genes viz., cryl, cry2, cry4 and cry9 and 

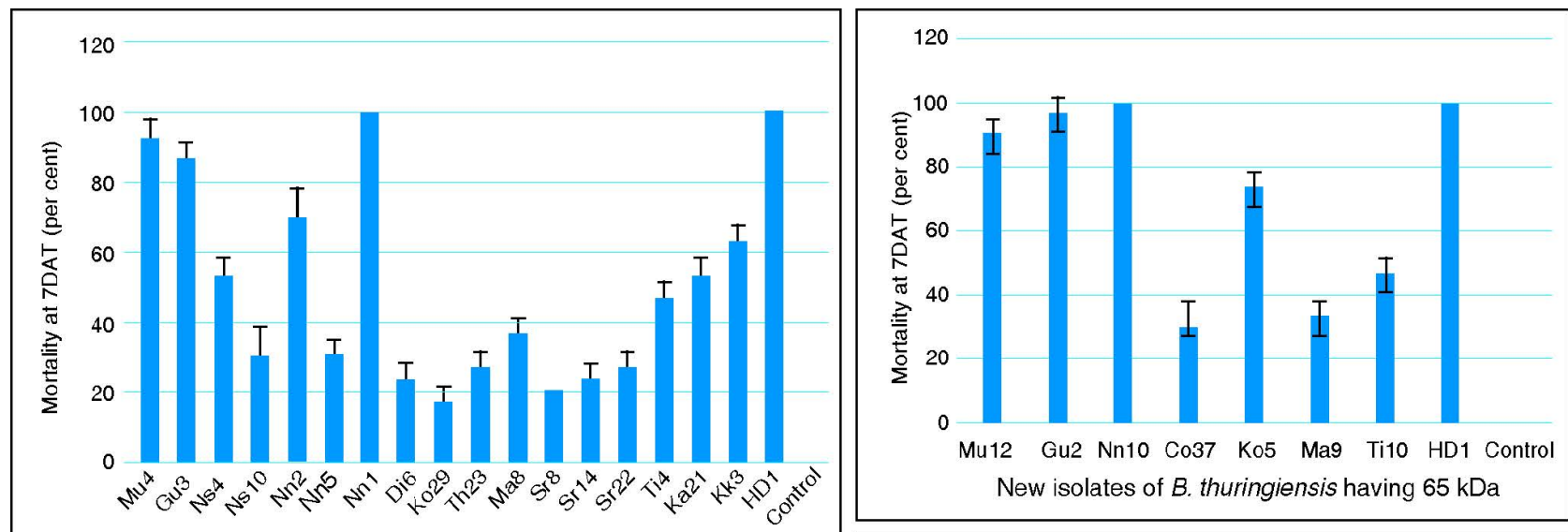

New isolates of $B$. thuringiensis having $135 \& 65 \mathrm{kDa}$

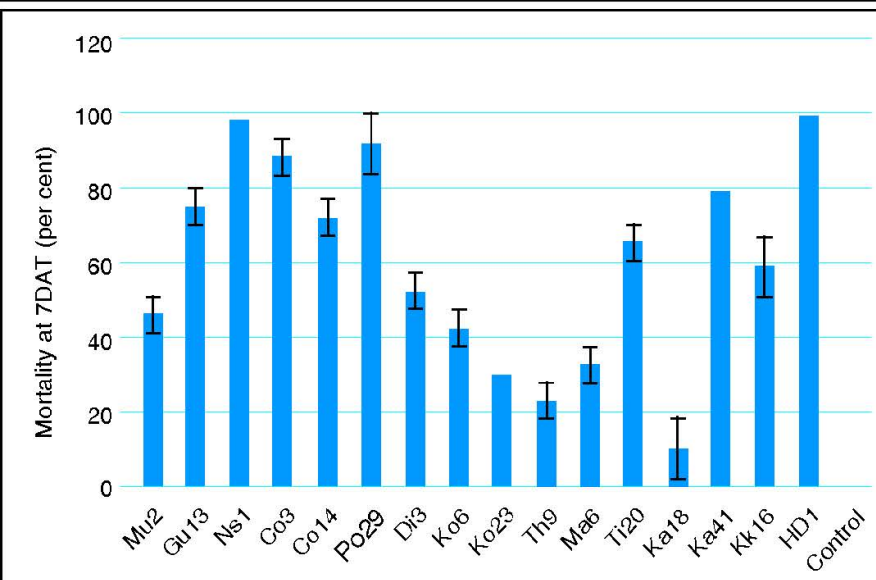

New isolates of $B$. thuringiensis having $135 \mathrm{kDa}$
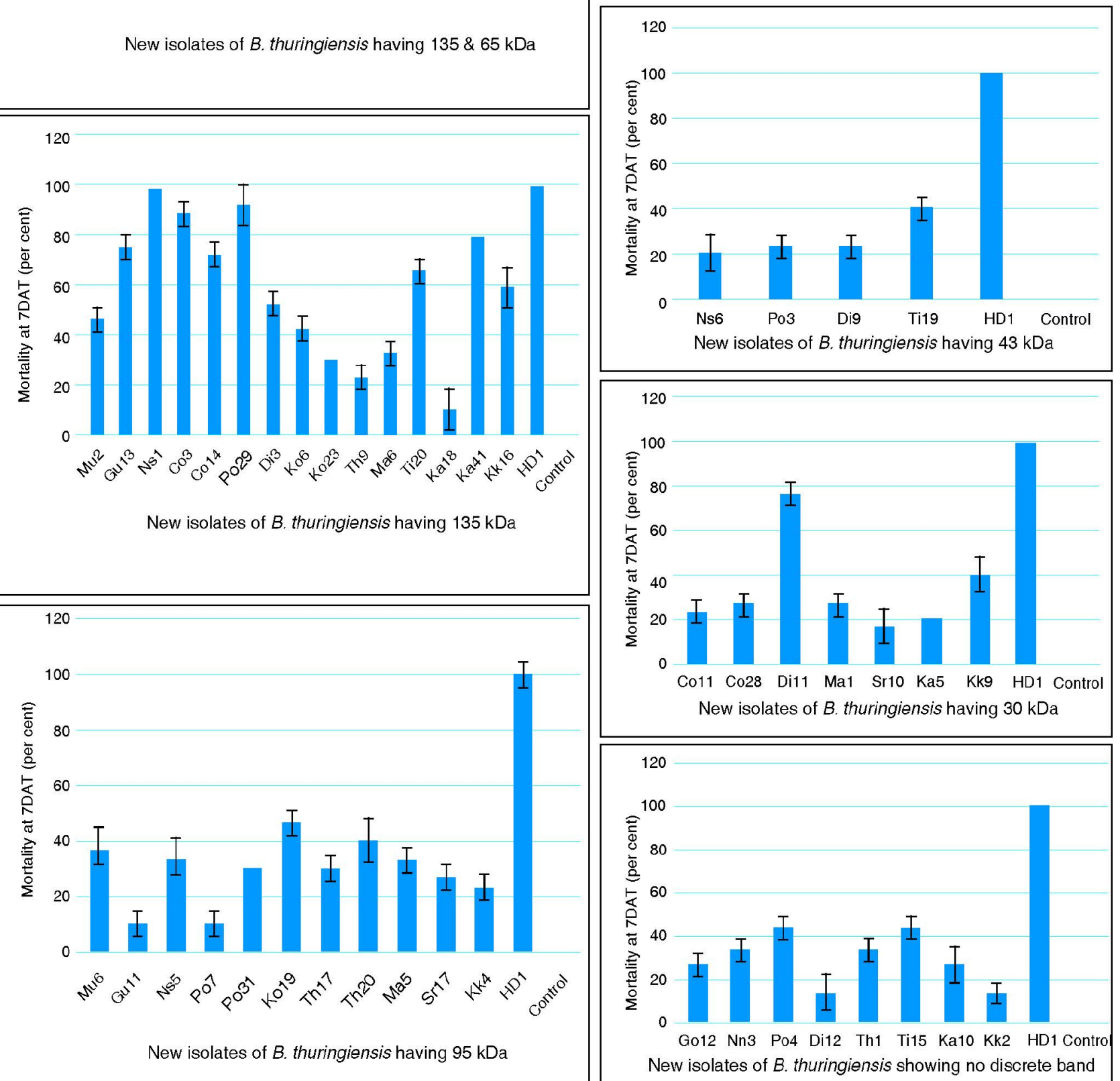

Fig. 1: Analysis of new isolates of $B$. thuringiensis for toxicity against $H$. armigera 
cry1 genes

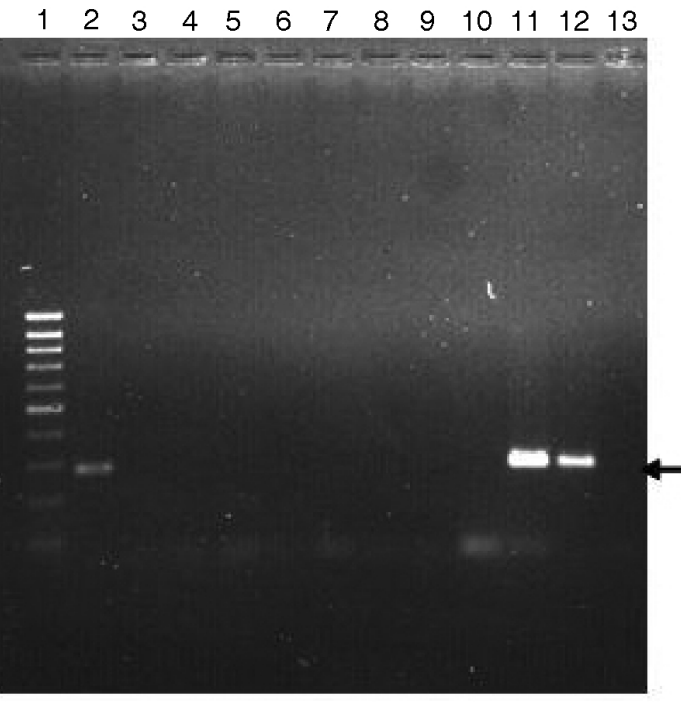

Line 1: 100bp marker; Lane 2 to 11: new isolates of $\mathrm{Bt}$; Lane 12: positive control (HD1); Lane 13: negative control cry2 genes

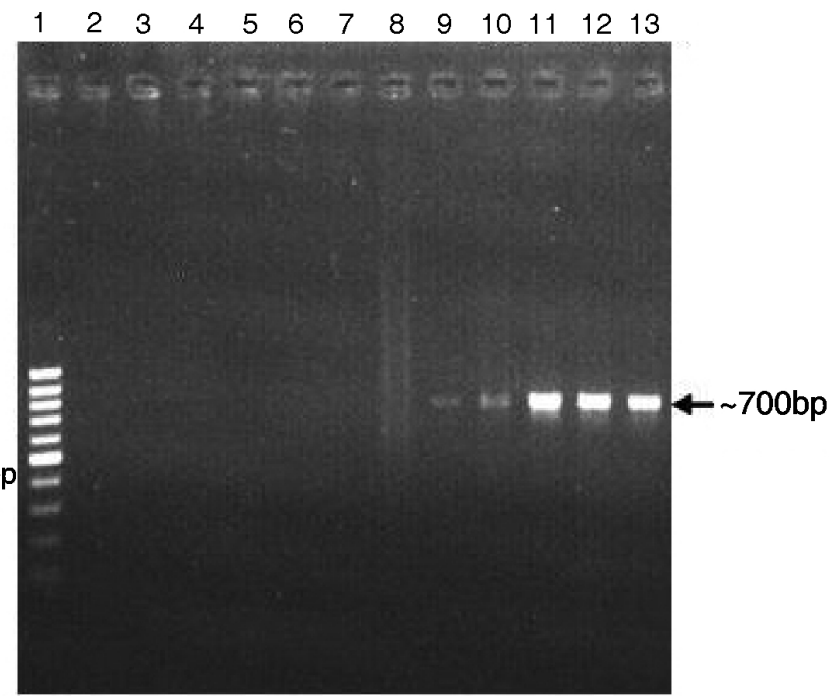

Line 1: 100bp marker; Lane 2 to 12: new isolates of $\mathrm{Bt}$; Lane 13: positive control (HD1) cry4 genes

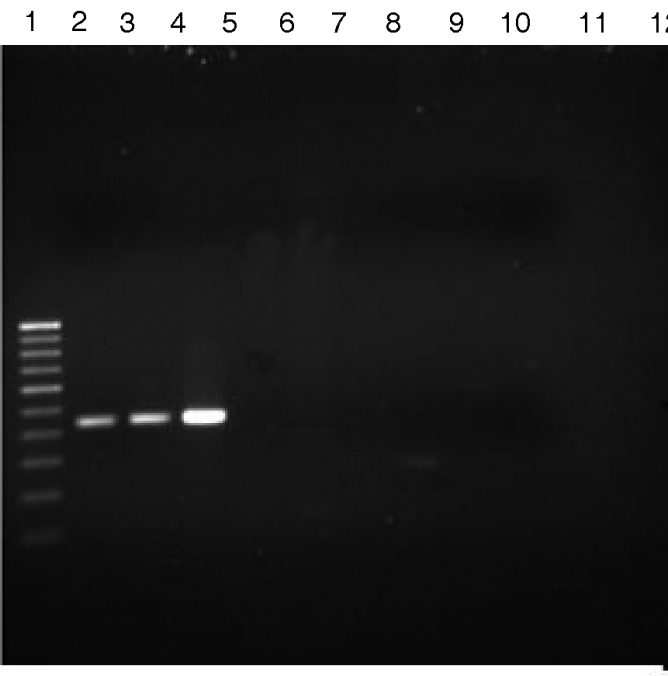

Line 1: 100bp marker; Lane 2: Positive control (Bti); Lane 3 to 11: new isolates of Bt; Lane 12: negative control cry9 genes

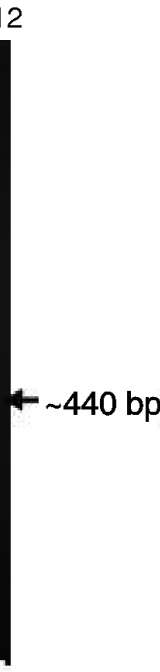

$$
\text { Line }
$$

1: $100 \mathrm{bp}$ marker; Lane 2 to 13: new Lane 15: negative control

Fig. 2: Analysis of cry gene profiles in new isolates of Bacillus thuringiensis by PCR

showed six different cry gene profile(s) viz., cryl; cry 2 ; cry 4 ; cry 1 \& cry 2 ; cry 2 \& cry 9 ; and cryl, cry2 \& cry9 genes (Table 4$)$.

\section{Discussion}

Several attempts have been made to determine the insecticidal activity of Bt strains isolated from different environments against the target insect species belonging to orders Lepidoptera, Coleoptera and Diptera using spore-crystal preparations (Bravo et al., 1998). In the present study, the efficacy of new isolates of $\mathrm{Bt}$ compared with HD1 against the 
Table 3: Crystal protein and cry gene profile of Group I isolates (90-100 \% mortality)

\begin{tabular}{lcc}
\hline Isolate name & $\begin{array}{c}\text { Crystal protein(s) } \\
(\mathrm{KDa})\end{array}$ & cry gene profile(s) \\
\hline $\mathrm{Mu} 4$ & $135 \& 65$ & cryl, cry2, cry9 \\
$\mathrm{Nn} 1$ & $135 \& 65$ & cry1, cry2 \\
Mu12 & 65 & cry2 \\
Gu2 & 65 & cry2 \\
Nn10 & 65 & cry2 \\
Ns1 & 135 & cryl \\
Co3 & 135 & cryl \\
Po29 & 135 & cryl \\
\hline
\end{tabular}

Table 4: Types of cry gene profile in B. thuringiensis isolates of Western Ghats

\begin{tabular}{llcc}
\hline S.No. & Presence of cry gene(s) & \multicolumn{2}{c}{ Bt isolates } \\
\cline { 3 - 4 } & & No. out of 70 & Per cent \\
\hline 1. & cry1 & 12 & 17.1 \\
2. & $c r y 2$ & 6 & 8.6 \\
3. & $c r y 4$ & 9 & 12.8 \\
4. & $c r y 1 \& 2$ & 8 & 11.4 \\
5. & $c r y 2 \& 9$ & 2 & 2.9 \\
6. & cry1,2 \& 9 & 9 & 12.8 \\
& Negative for all five $c r y$ & 24 & 34.3 \\
& genes screened & & \\
& Total & $\mathbf{7 0}$ & \\
\hline
\end{tabular}

lepidopteran pest of cotton, $H$. armigera revealed that high variability exist among the new isolates of $\mathrm{Bt}$ in terms of toxicity. The eight isolates having 135 \& 65 or 135 or $65 \mathrm{kDa}$ crystal proteins showed 100 per cent mortality; may be related to the Cry1 and Cry2 proteins groups which are known to be effective against lepidopteran insects. Forty eight of the $70 \mathrm{Bt}$ isolates screened for toxicity recorded less than 50 per cent mortality. Among them, 21 isolates showed $\sim 95$ or 43 or $30 \mathrm{kDa}$ crystal proteins. These isolates with uncommon sizes of crystal proteins may be more toxic to other lepidopteran insects or insects of other orders such as dipteran or coleopteran. Chilcott and Wigley, (1993) reported that 130,65 , and $28 \mathrm{kDa}$ proteins are mosquitocidal and $73 \mathrm{kDa}$ proteins are Coleopteran active. Information pertaining to toxicity of the new isolates presented in the present study is a preliminary screening of the isolates against one target insect, $H$. armigera. Further studies on toxicity analysis of purified crystal protein(s) against insects of different orders (groups) will throw more light on the insecticidal potency of the new isolates of Bt. PCR-based methods have been developed for identification of $\mathrm{Bt}$ isolates having novel cry gene profiles (Porcar and Juarez-Perez, 2003). PCR being a highly sensitive and relatively fast technique is especially suitable for rapid and large scale screening of Bt isolates. Bt strains harbouring novel cry genes and also the less frequently observed cry genes have been identified by PCR using specially designed primers corresponding to the highly conserved regions (Bravo et al., 1998).

In the present study, four of the five cry genes (cryl, cry2, cry 4 and cry9) were found in 46 of the 70 new isolates of Bt. Among them, the cryl gene was present in most of the isolates (41.4 per cent) followed by cry 2 gene (35.7 per cent). None of the $\mathrm{Bt}$ isolates showed positive result for cry 3 gene. The same trend has also been found in the previous studies conducted by Bravo et al. (1998); Kim (2000), who reported that the cryl gene has been found to be most abundant in every region and source followed by the cry 2 gene. On the other hand, 24 of the 70 isolates failed to generate a specific amplicon for any of the five cry genes tested (cryl, cry2, cry3, cry 4 and $\operatorname{cry} 9$ ). However out of 24 isolates, four viz., Ko19, Co14, Di3 and Di11 showed 50 to 89 per cent mortality of $H$. armigera and failed to give amplification of lepidopteran specific cryl, cry 2 and cry9 genes. Therefore, the toxicity observed in these four isolates may be due to the presence of other than cryl, cry 2 and cry 9 lepidopteran specific cry genes such as cry 15 or due to proteins encoded by novel cry gene(s). The remaining 20 isolates which did not give for any of the five cry genes tested showed less than 50 per cent mortality of $H$. armigera. Hence, it may be suggested that cry genes specific to insects of other orders such as Diptera/Coleoptera may be present in these isolates. Further studies on these 24 isolates, especially the four which showed more than 50 per cent mortality of $H$. armigera with degenerate primers will be useful to identify novel cry genes. 


\section{References}

Ben-Dov E, AZaritsky A, Dahan E, Barak Z, Sinai R, Manasherob R, Khameraev A, Troyetskaya A, Dubitsky A, Berezina $\mathrm{N}$ and Margalith Y (1997) Extended screening by PCR for seven cry-group genes from field-collected strains of Bacillus thuringiensis Appl Environ Microbiol 63 48834890

Ben-Dov E, Zaritsky A, Dahan E, Barak Z, Sinai R, Manasherob R, Khameraev A, Troyetskaya A, Dubitsky A, Berezina $\mathrm{N}$ and Margalith Y (1997) Extended screening by PCR for seven cry-group genes from field-collected strains of Bacillus thuringiensis Appl Environ Microbiol 63 48834890

Bravo A, S Sarabia, L Lopez, H Ontiveros, C Abarca, A Ortiz, M Soberon and R Quintero (1998) Characterization of cry genes in a Mexican Bacillus thuringiensis strain collection Appl Environ Microbiol 64 4965-4972

Brookes G and P Barfoot (2010) Global Impact of Biotech Crops: Environmental Effects, 1996-2008 Ag Bio Forum 13 7694

Chilcott C N and Wigley P J (1993) Isolation and toxicity of Bacillus thuringiensis from soil and insect habitats in New Zealand Journal of Invertebrate Pathology 61 244-247

Kalman S, K L Kiehne, J L Libs and T Yamamoto (1993) Cloning of a novel cryIC-type gene from a strain of Bacillus thuringiensis subsp. galleriae Appl Environ Microbiol 59 1131-1137

Kim H S (2000) Comparative study of the frequency, flagellar serotype, crystal shape, toxicity, and cry gene contents of Bacillus thuringiensis from three environments Curr Microbiol 41 250-256

Patel R C, Patel J K, Patel P B and Singh R (1968) Mass breeding of Heliothis armigera (Hbn.) Indian J Entomol 30 272280

Porcar M and V P Juarez-Perez (2003) PCR-based identification of $B$. thuringiensis pesticidal crystal genes FEMS Microbiol Rev 26 419-32

Ramalakshmi A and Udayasuriyan V (2010) Diversity of Bacillus thuringiensis isolated from Western Ghats of Tamil Nadu State, India Curr Microbiol 61 13-18

Sambrook J Fritschi E F and Maniatis T (1989) Molecular cloning: a laboratory manual, Cold Spring Harbor Laboratory Press, New York

Xue J, Liang G, Crickmore N, Li H, He K, Song F, Feng X, Huang D and Zhang $J$ (2008) Cloning and characterization of a novel Cry1A toxin from Bacillus thuringiensis with high toxicity to the Asian corn borer and other lepidopteran insects Microbiol Lett 280 95-101. 